\title{
Comparative study of cytological and histopathological finding in breast lesion
}

\author{
Dr.Manju.T.Vala*, Dr.Alpesh. Goswami**, Dr.S.K.Suri *** \\ * Resident Doctor, **Associate Professor, ${ }^{* * *}$ Head of Department of Pathology, Government Medical \\ College, Bhavnagar-364001
}

\begin{abstract}
Aim \& Objective: To study the morphological aspects of various breast lesions in patients with an apparent breast lump. To correlate the cytological findings with histopathological examination.To determine the accuracy of aspiration cytology in the diagnosis of the breast lesions. To analyse the causes of the diagnostic error and ways of overcoming them.

Materials \& Methods: The present study included 35 cases presenting with palpable breast lump in the outpatient department of the Sir T Hospital Bhavnagar. FNA was carried out on all of them and the material studied in the Department of pathology, Medical College, Bhavnagar, from January 2012 to February 2014. All cases were also subjected to surgical biopsy or mastectomy.

Results: Out of 35 cases 25 cases were diagnosed as benign breast lesions and 10 cases were diagnosed as malignant breast lesions on cytology. On histological examination out of 25 benign lesions only 02 shows carcinoma while all malignant lesions were confirmed. The sensitivity, specificity, positive predictive value, negative predictive value and accuracy was $83.33 \%, 100 \%, 100 \%, 92 \%$ and $94.2 \%$ respectively.

Conclusion: In conclusion, the simplicity, rapidity, lack of morbidity, a high sensitivity, a high specificity and cost effectiveness of FNAC makes it the most valuable tool in the evaluation of the breast lesion.
\end{abstract}

\section{Introduction}

Breast carcinomas are one of the leading causes of cancer in women. Fine Needle Aspiration Cytology (FNAC) is one of the important components of 'triple approach', which has been widely accepted for the preoperative diagnosis of breast lesions. It is a multi-disciplinary approach that includes analysis of clinical and radiological findings in conjunction with FNAC features, to diagnose the breast lesions and to determine the best management plan for the patient.

Most cases of breast lumps are benign, but sometimes, it is difficult to determine whether a suspicious lump is benign or malignant, simply by doing a clinical examination. In these circumstances, as a widely accepted and established outdoor patient procedure, FNAC plays an important role in determining the nature of the lump. FNAC can reduce the number of open breast biopsies.

Histopathological examinations for breast lesions To determine the accuracy of fine needle aspiration cytology in the diagnosis of breast lesions.

\section{Aims and objectives}

To correlate the cytological findings with histopathological examinations for breast lesions.

To determine the accuracy of fine needle aspiration cytology in the diagnosis of breast lesions.

\section{Material and Methods}

The present study included 35 cases presenting with palpable breast lump in the outpatient department of the Sir T Hospital Bhavnagar from January 2012 to February 2014. FNA was carried out using $10 \mathrm{ml}$ plastic disposable syringe and disposable needles of 23-24gauge on all of them, stained with H \& E and Giemsa stain and the material studied in the Department of pathology, Medical College, Bhavnagar. FNA was performed on all the palpable lumps without local anaesthesia.

All female with unknown primary diagnosis of breast mass/lumps undergoing FNAC followed by excision biopsy/lumpectomies or mastectomy are included in present study.And Patients with recurrent malignancy,patients who underwent FNAC but did not undergo subsequent histopathological diagnosis and Patients undergoing chemotherapeutic treatment are excluded in present study. . All cases were also subjected to surgical biopsy or mastectomy

\section{Results}

The age range of total 35 patients was 15-60 years. Out of these 35 patients 23 patients had benign lesions and 12 had malignant lesion. The highest frequency of benign breast lumps were mostly in the age range 
of 15-30 years and the highest frequency of malignant breast lumps were found in the age group of 40-60 years (figure 1).

This study includes 35 cases presenting with a palpable breast lump which were subjected to fine needle aspiration. For all cases which were studied in cytology, histopathological correlation was available. Out of 25 benign cases in cytological study 2 were diagnosed as malignant in histopathological study, and all malignant cases in cytological study were confirmed as a malignant in histopathological study. Thus out of 35 cases, in 33 cases cytological diagnosis was consistent with histopathological diagnosis giving accuracy rate of $94.2 \%($ table 1$)$.

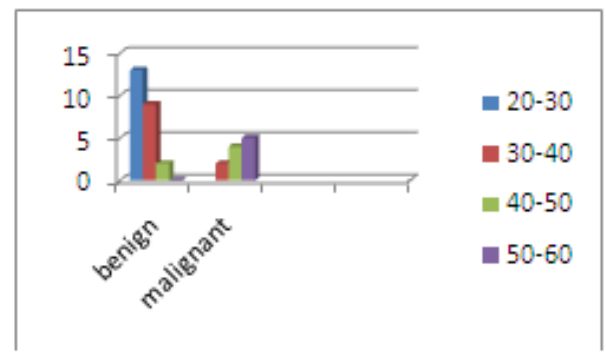

Figure -1

\begin{tabular}{|l|l|l|l|}
\hline \multicolumn{4}{|l|}{ Table-1:Cytological diagnosis of breast lesion by FNAC } \\
\hline Category & $\begin{array}{l}\text { Cytological } \\
\text { Diagnos }\end{array}$ & $\begin{array}{l}\text { No. of } \\
\text { cases }\end{array}$ & Percentage \\
\hline $\begin{array}{l}\text { Inflammatory } \\
\text { Lesions } \\
(50 \\
22.52 \%\end{array}$ & Abscess/mastitis & 02 & $5.7 \%$ \\
\cline { 2 - 4 } & $\begin{array}{l}\text { Granulomatous } \\
\text { mastitis }\end{array}$ & 01 & $2.8 \%$ \\
\hline $\begin{array}{l}\text { Benign breast } \\
\text { lesion }\end{array}$ & Fibroadenoma & 16 & $45.7 \%$ \\
\cline { 2 - 4 } & Fibrocystic disease & 03 & $8.5 \%$ \\
\cline { 2 - 4 } & $\begin{array}{l}\text { Epithelial } \\
\text { hyperplasia }\end{array}$ & 01 & $2.8 \%$ \\
\cline { 2 - 4 } & Simple cyst & 01 & $2.8 \%$ \\
\hline $\begin{array}{l}\text { Atypical } \\
\text { intermediate } \\
\text { Probably benign }\end{array}$ & $\begin{array}{l}\text { Ductalhyperplasia } \\
\text { with atypia }\end{array}$ & 01 & $2.8 \%$ \\
\hline Malignancy & Ductal carcinoma & 09 & $25.7 \%$ \\
\cline { 2 - 4 } & Papilloma & 01 & $2.8 \%$ \\
\hline Total & \multicolumn{2}{|l}{} \\
\hline
\end{tabular}

\begin{tabular}{|c|c|c|c|c|c|c|c|c|c|c|c|}
\hline \multicolumn{12}{|c|}{ Table-2:Cyto-histopathological correlation \& statistical evaluation of breast lesions } \\
\hline \multirow[t]{2}{*}{ Studies } & \multirow{2}{*}{$\begin{array}{l}\text { No of } \\
\text { benign } \\
\text { lesion }\end{array}$} & \multicolumn{2}{|c|}{$\begin{array}{l}\text { Histological } \\
\text { diagnosis }\end{array}$} & \multirow{2}{*}{$\begin{array}{l}\text { No. of } \\
\text { malignant } \\
\text { lesion }\end{array}$} & \multicolumn{2}{|c|}{$\begin{array}{l}\text { Histological } \\
\text { diagnosis }\end{array}$} & \multirow{2}{*}{$\begin{array}{l}\text { No of } \\
\text { suspicious } \\
\text { Malignane } \\
y\end{array}$} & \multicolumn{2}{|c|}{$\begin{array}{l}\text { Histological } \\
\text { diagnosis }\end{array}$} & \multirow{2}{*}{$\begin{array}{l}\text { Sens } \\
\text { itivit } \\
y\end{array}$} & \multirow[t]{2}{*}{$\begin{array}{l}\text { Specificit } \\
y\end{array}$} \\
\hline & & Benign & Malignant & & $\begin{array}{l}\text { Malign } \\
\text { ant }\end{array}$ & Benign & & $\begin{array}{l}\text { Malign } \\
\text { ant }\end{array}$ & Benign & & \\
\hline $\begin{array}{l}\text { Tiwari } \\
\mathrm{M}[6]\end{array}$ & 16 & $\begin{array}{l}15 \\
(93.75 \\
\%)\end{array}$ & $\begin{array}{l}01 \\
(6.25 \%)\end{array}$ & 05 & $\begin{array}{l}05 \\
(100 \%\end{array}$ & $\begin{array}{l}00 \\
(00 \%)\end{array}$ & - & - & - & $\begin{array}{l}83.3 \\
\%\end{array}$ & $100 \%$ \\
\hline $\begin{array}{l}\text { O'Neil } \\
S \text { et al., } \\
{[9]}\end{array}$ & 166 & $\begin{array}{l}153 \\
(92.17 \\
\%)\end{array}$ & $\begin{array}{l}13 \\
(7.83 \%)\end{array}$ & 401 & $\begin{array}{l}398 \\
(99.25 \\
\%)\end{array}$ & $\begin{array}{l}03 \\
(0.75 \%)\end{array}$ & 125 & $\begin{array}{l}84 \\
(67.20 \\
\%)\end{array}$ & $\begin{array}{l}41 \\
(32.80 \%\end{array}$ & $97 \%$ & $78 \%$ \\
\hline $\begin{array}{l}\text { Zhang } \\
\text { Qin et } \\
\text { al., [7] }\end{array}$ & 215 & $\begin{array}{l}213 \\
(99.07 \\
\%)\end{array}$ & $\begin{array}{l}02 \\
(\% 0.93)\end{array}$ & 73 & )$^{73}(100 \%$ & $\begin{array}{l}00 \\
(00 \%)\end{array}$ & 28 & $\begin{array}{l}26 \\
(92.86 \\
\%)\end{array}$ & $\begin{array}{l}02 \\
(7.14 \%)\end{array}$ & $\begin{array}{l}97.1 \\
\%\end{array}$ & $97.3 \%$ \\
\hline $\begin{array}{l}\text { A.Z. } \\
\text { Moham } \\
\text { med et } \\
\text { al., [8] }\end{array}$ & 61 & $\begin{array}{l}58 \\
(95.08 \\
\%)\end{array}$ & $\begin{array}{l}03 \\
(4.92 \%)\end{array}$ & 27 & $\begin{array}{l}27 \\
(100 \%\end{array}$ & $\begin{array}{l}00 \\
(00 \%)\end{array}$ & $\begin{array}{l}02 \\
(2.15 \%)\end{array}$ & $\begin{array}{l}02 \\
(100 \%\end{array}$ & $\begin{array}{l}00 \\
(00 \%)\end{array}$ & $\begin{array}{l}90.6 \\
\%\end{array}$ & $100 \%$ \\
\hline $\begin{array}{l}\text { In } \\
\text { present } \\
\text { study }\end{array}$ & 25 & $\begin{array}{l}23 \\
(92 \%)\end{array}$ & $\begin{array}{l}02 \\
(8 \%)\end{array}$ & 10 & $\begin{array}{l}10 \\
(100 \%\end{array}$ & $\begin{array}{l}00 \\
(00 \%)\end{array}$ & $\cdot$ & - & $\cdot$ & $\begin{array}{l}33.3 \\
3 \%\end{array}$ & $100 \%$ \\
\hline
\end{tabular}




\section{Discussion}

FNAC of breast lumps is an accepted and established method for determining the natures of breast lumps with a high degree of accuracy ${ }^{[2,3]}$. Application of Fine Needle Aspiration (FNA) for the diagnosis of palpable breast masses was first introduced by Martin and Ellis in 1930 and since then, it has been established as an important tool in the evaluation of breast lesions

Most of the patients with breast lumps are in a state of anxiety. So, in reducing anxiety and unnecessary surgical procedures as well as in minimization of delay in the diagnosis, FNAC proves very fruitful. FNA procedure is a safe method with only a few reported complications. It has been reported in the literature that the incidence of tumour transplantation along the needle track by FNA procedure is only about $0.0045 \%$, and even much lower in superficially located tumours ${ }^{[4]}$.

Bell $9^{[5]}$ had stated that aspiration cytology was accurate, rapid and of value in the assessment and management of patient in office practice. Documentation of the presence of breast cancer by FNAC might Obviate the need for a two stage procedure in the surgical management of breast cancer. In our institution also FNAC is being used as basic test for surgical management of malignant breast lesions; after surgery the whole specimen is submitted for histopathological examination and confirmation of malignancy. In the present study, all the 10 cytologically diagnosed malignant cases were confirmed as malignant on subsequent histopathological examinations. So, in our study, a 100\% cyto-histopathological correlation was observed for malignant lesions. Zhang Qin et al ${ }^{[7]}$, AZ Mohammed et al ${ }^{[8],}$ Tiwari $\mathrm{M}^{[6]}$ had also observed the same results in their studies (table2).

\section{Conclusion}

The present study shows that FNA is a reliable method. It helps to confirm the clinical diagnosis without open biopsy. It helps to take the decision for mode of surgery. From this study it can be concluded that diagnosis of breast lesion based on FNAC should be practiced as a routine procedure as there is high degree of correlation with histopathologic findings. FNAC is also an ideal method for patients follow up if there is recurrence of breast lump. In the presence of budget constraints and personnel shortage, hospitals are required to demonstrate even great cost effectiveness in the diagnosis of breast lesions. Accurate preoperative assessment of breast lesions is becoming increasingly important. FNAC should be used as a routine diagnostic procedure due to its cost effectiveness, thus maximizing the availability of health care to patients with breast lesions. Some false negative results are inevitable. Sampling errors and interpretation errors are responsible for false negative results. However due to the false negative cytologic diagnosis seen in most series, all clinically malignant or suspicious masses should have a biopsy in the face of a benign cytology.

\section{References}

[1]. Hindle WH, Payne PA, Pan EY. The use of fine needle aspiration in the evaluation of persistent palpable dominant breast masses. Am J Obstetrics Gynaecol. 1993; 168 (6 Part 1): 1814-18

[2]. Purasiri P, Abdalla M, Heys SD, Ah-See AK, McKean ME, Gilbert FJ, et al. A novel diagnostic index for use in the breast clinic. J R CollSurgEdinb. 1996; 41: 30- 34 .

[3]. Kaufman Z, Shpitz B, Shapiro M, Rona R, Lew S, Dinbar A. Triple approach in diagnosis of dominant breast masses: combined physical examination, mammography and fine-needle aspiration. J SurgOncol. 1994; 56: 254-57.

[4]. Haddad FS. Re: Risk factors forperineal seeding of prostate cancer afterneedle biopsy. J Urol. 1990; 143: 587-88

[5]. Bell D.A. et al: Role of aspirationcytology in the diagnosis andmanagement of mammary lesions in officepractise. Cancer1983; 51: 1182-1189

[6]. Tiwari M. Role of FNAC in diagnosis of breast lumps. Kathmandu University Medical Journal. 2007; 5: $215-17$.

[7]. Zhang Qin, NieShigui, Chen Yuhua, Zhou Limei. Fine NeedleAspirationCytology of Breast Lesions: Analysis of 323 Cases. The Chinese-German Journal of Clinical Oncology. 2004; 3(3): 172-74.

[8]. Mohammad AZ, Edino ST, Ochicha O, Alhassan SU. Value of fine needle aspiration biopsy in preoperative diagnosis of palpable breast lumps in resource-poor countries: a Nigerian experience. Annals of African Medicine. 2005; 4(1): 19-22.

[9]. O’Neil S, Castelli M, Gattuso P, Kluskens L, Madsen K, Aranha G. Fine-needle aspiration of 697 palpable breast lesions with histopathologic correlation. Surgery. 1997; 122(4): 824-28. 